\title{
ラットの消化管組織形態に及ぼす食物繊維の影響
}

\author{
青 江 誠一郎*,**, 太田冨貴雄**, 綾 野 雄 幸** \\ * 雪印乳業（株）技術研究所 \\ ** 千葉大学園芸学部農芸化学科
}

\section{Effects of Dietary Fiber on Histological Changes in the Rat Gastrointestinal Tract}

\author{
Seiichiro AOE,*,** Fukio OHTA** and Yūkō AYANO** \\ * Technical Research Institute, Snow Brand Milk Products \\ Co., Ltd., Kawagoe 350 \\ ** Department of Agricultural Chemistry, Faculty of Horticulture, \\ Chiba University, Matsudo 271
}

\begin{abstract}
Nippon Eiyō Shokuryō Gakkaishi (J. Jpn. Soc. Nutr. Food Sci.) 42, 139 145 (1989)
The effects of dietary fiber on histological changes in the gastrointestinal tract of rats were studied. A fiber-free diet was supplied for 17 days to a control group and a diet containing $2 \%$ rice bran hemicellulose (RBH), high-methoxylated pectin (HMP), or microcrystalline cellulose (MCC) was given to one of three other groups. Weight gain and feed efficiency were greater in the dietary fiber groups than in the control group. Light microscopy (LM) and scanning electron microscopy (SEM) were used to examine the structural changes in the alimentary tract after these dietary manipulations. Mild swelling of the villi was observed by $\mathrm{LM}$ in the jejunum of rats fed the $2 \% \mathrm{RBH}$ and HMP diets. Irregular villi were found by SEM in the jejunum and ileum of rats fed the water-soluble dietary fiber, especially HMP. Swelling at the villus tips was revealed by LM throughout the small intestine of rats fed MCC. The present results suggest that the structural modifications induced by a $2 \%$ level of these dietary fibers did not affect the functional characteristics of the gastrointestinal tract because weight gain and feed efficiency were greater in the dietary fiber groups than in the control group.
\end{abstract}

(Received August 19, 1988)

食物瀻維（dietary fiber，以下 DF と略す）が生体に 及ぼす効果は，非常に多岐にわたり，そのメカニズムも 多様である。疫学的調査により示された DF の抗動脈硬 化性作用や抗腫瘍性作用は，おもに，胆汁酸結合能，保 水能力, 腸管通過時間短縮, 腸内菌叢の修飾，栄養成分 の吸収阻害などと関連していると考学られている122)。

DF の生理化学作用は，一般的に，摂取した食事成分 および，消化酵素あるいは消化管ホルモンの分泌，腸内 菌叢などの内因性あるいは食物などの外因性因子との相 互作用を中心考兄られているが，DF が直接的に消化 管粘膜に作用し，生体の吸収能力を修飾するといら考兄 もある ${ }^{3)}$ 。Jacobs 5 ${ }^{4)}$ は，小麦フスマを $20 \%$ 含む飼料を ラットに投与すると, 遠位結腸の粘膜内の白血球が増加 し, 近位結腸の細胞内 RNA が減少する結果, 小麦フス マが結腸粘膜細胞の增殖に影響を与えることを報告して

* 个350 川越市南台 1-1-2

** 厂271 松戸市松戸 648
いる。Paulini ら5)は，サイリウム $10 \%$ 添加食をアフリ カミドリザルに長期間与兄ると, 小腸の䄉毛の腫張, 䄉 毛構造の不規則化や微䋐毛の剝離，不規則化が小腸䋐毛 先端で観察されることを報告している。これらの実験 は，精製ないし半精製された DF を 10２0\% 飼料に添 加するといった，比較的高レベル投与の際の影響を調べ たものがほとんどである。しかし，現実的には，これら DF が摄取される量は，食事撕取量に対し， $5 \%$ 以下で あることが多いと考光られる。損取すべき DF の質と量 が問われるよらになってきている現在, 種々の添加レべ ルでの検討は重要である。

水溶性 DF として，すでにいくつかの生理効果が報告 されている米ヌカへミセルロース標品 $(\mathrm{RBH})^{677)}$ ならび

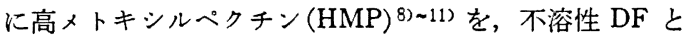
して，微結晶七ルロース（MCC）を用いた。 RBH およ びHMPは，1 ～ $5 \%$ レベルの比較的低レベルの投与で も，ラットのコレステロール代謝や腸内菌丵などに影響 
Table 1. Composition of hemicellulose preparation isolated from defatted rice bran.

\begin{tabular}{lc}
\hline \hline Components & \% of dry matter \\
\hline Cellulose $\left.^{a}\right)$ & 0.2 \\
Non-cellulosic polysaccharidea) & 68.9 \\
& Glucose \\
b) $\left\{\begin{array}{l}\text { Arabinose } \\
\text { Xylose }\end{array}\right.$ Galactose & 25.9 \\
Mannose & 25.1 \\
Uronic acidc) & 3.6 \\
Lignina) & nd. \\
Total nitrogen & 6.0 \\
Ash & 2.4 \\
\hline \hline
\end{tabular}

a) Measured by method of Southgate. b) The individual neutral sugars measured as alditol acetates by gas chromatography. c) Uronic acid measured by decarboxylation method.

を与えることが知られている67711。本研究は, これら の DF を $2 \%$ 実験飼料に添加して， ラットに投与した 際の消化管組織の形態変化こついて, 組織標本の光学顕 微鏡 $(\mathrm{LM})$ ならびに走查型電子顕微鏡 (SEM) による検 索を行ったものである。

\section{実 験 方 法}

\section{1. 実験試料}

水溶性 DF として, RBH ならびに HMP（エステル 化度 $65 \%$, Brown NF, UNIPECTIN) を, 不溶性 DF として，MCC（RC-591，AVICEL) を用いた。

“へミセルロースB”を主体とした RBH の調製は. 脱脂米ヌカから以下の方法により抽出, 分離した6)7。 すなわち、グルコアミラーゼ溶液を用いて, 脱脂米ヌカ からでんぷんを除去した後， $0.5 \mathrm{~N}$ 水酸化ナトリウム溶 液で抽出した。抽出液を分離後, トリクロロ酢酸にて除 タンパクし, 中和, 透析, アルコール精製, 凍結乾燥を 行い, 標品とした。収量は, 脱脂米ヌカ $100 \mathrm{~g}$ 当たり約 $4.5 \mathrm{~g}$ であった。 $\mathrm{RBH}$ の成分分析は, Southgate 法12) により行った。また，糖組成については，Southgate 法 の加水分解条件で処理した後, アルディトールアセチル 化 $^{13)}$ し, ガスクロマトグラフ法で測定した。ウロン酸に ついては,カルパゾール硫酸法により測定した14)。 $\mathrm{RBH}$ の成分を Table 1 に示す。この RBH は, 非セルロー ス多糖類が大半を占め, 構成糖は, キシロースとアラビ ノースがおもなものであった。

\section{2. 動物実験}

実験飼料の組成をTable 2 に示す。DF 無添加飼料は $\alpha$-コーンスターチを糖質源としたもので, DF 各添加飼
Table 2. Composition of diet (\%).

\begin{tabular}{lccc}
\hline & $\begin{array}{c}\text { Fiber- } \\
\text { free }\end{array}$ & $\begin{array}{c}\text { Water- } \\
\text { soluble } \\
\text { DFa) }\end{array}$ & Celluloseb) \\
\hline Casein & 22 & 22 & 22 \\
Lard & 9 & 9 & 9 \\
Corn oil & 1 & 1 & 1 \\
Salt mixturec) & 3.5 & 3.5 & 3.5 \\
Vitamin mixturec) & 1 & 1 & 1 \\
Choline chloride & 0.2 & 0.2 & 0.2 \\
Dietary fiber & - & 2 & 2 \\
$\alpha$-Corn starch & 63.3 & 61.3 & 61.3 \\
\hline \hline
\end{tabular}

a) Water-soluble dietary fiber: Rice bran hemicellulose $(\mathrm{RBH})$, High-methoxylated pectin (HMP).

b) Microcrystalline cellulose (MCC). c) Prepared according to AIN-76 prescription (1977 J. Nutr. $107: 1340$ ).

料は，この $\alpha$-コーンスターチを DF $2 \%$ でそれぞれ置 換したものを用いた。

体重 80 90 g の Sprague-Dawley 系雄ラット（日本 クレフ）を，DF 無添加飼料で 5 日間予備飼育した後， 1 群 3 匹ずつ 4 群に分け, Table 2 に示した実験飼料を それぞれ投与して 17 日間飼育した。なお，飼料および水 は自由に摂取させた。ラットは，実験終了日の翌日（一 夜絶食させた)，エーテル麻酔下で開腹し，ただちに， 胃 ·十二指腸 (胃下 $3 \mathrm{~cm}$ ) ·空腸 (胃下 $7 \sim 10 \mathrm{~cm}$ ) ・ 回 腸（盲腸より $5 \sim 8 \mathrm{~cm}$ 上部）・盲腸・結腸をそれぞれ摘 出した。これら部位から， $1 \mathrm{~cm}$ ずつ切りとり，生理食 塩水に浸して切開し, 内容物を取り除いた後, $10 \%$ ホル マリン溶液にて固定した。成長結果ならびに解剖時の結 果の統計処理は, 分散分析を行い, 平均値の差の検定 は, Tukey 型の多重比較法を用いた。

\section{3. 組樴標本の LM による検索 ${ }^{15)}$}

$10 \%$ ホルマリン固定組織を胃・十二指腸・空腸・回 腸・盲腸・結腸の部位に分けて切り出し，常法によりパ ラフィン包埋, 薄切, ヘマトキシリン・エオジン染色 (HE 染色)および封入の操作により組織標本を作製し, LM によって検索した。

\section{4. 消化管組織形態の SEM による検索 ${ }^{16)}$}

各ホルマリン固定組織を, 数 $\mathrm{mm}^{2}$ にカミソリで切断 し $0.1 \mathrm{M}$ リン酸緩衝液 $(\mathrm{pH} \mathrm{7.0)}$ にて 2 回洗浄後, $2.5 \%$ グルタールアルデヒドで 2 時間前固 定し， $0.5 \%$ オスミウム酸で一夜, 後固定した。固定後, 50 100\% のアルコール系列による脱水，イソアミル酢酸による置 換, 臨界点乾燥および金ーパラジウム合金イオンスパッ タコーティングし, SEM（日立 S-800）によって検索し 
Table 3. Effect of dietary fibers on body weight gain, feed intake and relative weight of liver to eviscerated carcass.

\begin{tabular}{lcccr}
\hline & Fiber-free & $\mathrm{RBH}$ & \\
\hline Initial weight $(\mathrm{g})$ & $125.9 \pm 1.4$ & $125.9 \pm 1.0$ & $126.2 \pm 1.5$ & $125.8 \pm 2.9$ \\
Final weight $(\mathrm{g})$ & $256.6 \pm 10.0$ & $261.7 \pm 5.8$ & $261.1 \pm 0.7$ & $259.8 \pm 10.2$ \\
Weight gain (g) & $130.7 \pm 8.7$ & $135.8 \pm 6.0$ & $134.9 \pm 2.1$ & $134.0 \pm 7.7$ \\
Feed intake (g) & $308.2 \pm 6.8$ & $305.8 \pm 9.5$ & $303.7 \pm 7.4$ & $307.1 \pm 3.7$ \\
Feed efficiency ${ }^{\mathrm{d}}$ ) & $0.42 \pm 0.02$ & $0.44 \pm 0.01$ & $0.44 \pm 0.01$ & $0.44 \pm 0.01$ \\
\hline Eviscerated carcass (g) & $194.6 \pm 7.4$ & $195.7 \pm 1.9$ & $195.1 \pm 0.6$ & $193.5 \pm 7.6$ \\
Carcass weight/body weight (\%) & $80.6 \pm 7.4$ & $79.9 \pm 1.3$ & $80.2 \pm 0.4$ & $78.9 \pm 0.2$ \\
Liver (\%) & $3.92 \pm 0.03$ & $4.10 \pm 0.27$ & $4.15 \pm 0.06$ & $4.25 \pm 0.07$ \\
\hline \hline
\end{tabular}

Values are Means \pm S.E. $(n=3)$.

a) Rice bran hemicellulose. b) High-methoxylated pectin. c) Microcrystalline cellulose. d) Weight gain/ Feed intake.

Table 4. The distribution of histological changes by dietary fibers.

\begin{tabular}{lllllllll}
\hline \hline \multirow{2}{*}{ Diet } & & \multicolumn{7}{c}{ Small intestinea) } \\
\cline { 3 - 8 } & & & Stomach & Duodenum & Jejunum & Ileum & Cecum & Colon \\
\hline Fiber-free & $\left.(3)^{b}\right)$ & $\left.(-)^{c}\right)$ & $(-)$ & $2(+)$ & $(-)$ & $(-)$ & $(-)$ \\
Rice bran hemicellulose & $(3)$ & $(-)$ & $(-)$ & $1(+)$ & $(-)$ & $(-)$ & $(-)$ \\
High-methoxylated pectin & $(3)$ & $(-)$ & $(-)$ & $1(+)$ & $(-)$ & $(-)$ & $(-)$ \\
Microcrystalline cellulose & $(3)$ & $(-)$ & $1(+)$ & $2(++) 1(+)$ & $2(+)$ & $(-)$ & $(-)$ \\
\hline
\end{tabular}

a) The changes in the small intestine were primarily swelling of villi. b) Number of rats. c) Values show number of rats affected : $(-)=$ No change; $(+)=$ Slight change; and $(++)=$ Significant change.

た。

\section{実 験 結 果}

\section{1. 動物実験}

成長結果を Table 3 に示す。RBH, HMP, MCC 各添 加群とも，成長は良好であり，DF 添加による下塺など の症状は認められなかった。増体重, 屠体重および飼料 効率は，各群間に有意差は認められなかったが，DFを 添加した群のほうが DF 無添加群に比ぺて, 増体重, 飼 料効率が高い傾向にあった。

\section{2. 組織標本の LM による検索}

各飼料投与群のラットの胃・十二指腸・空腸・回腸 · 盲腸・結腸の組織標本の LM による検索を行った。組織 学的に変化の認められた部位について, Table 4 にまと めた。また，空腸および回腸の典型的なLMによる像を Fig. 1，2 に示す。MCC 添加群の空腸〜回腸は, 䋐毛の 腫張の頻度が高かった（Fig.1 d, 2d)。また，空腸にお いて, DF 無添加群で2 例, RBH, HMP 添加群でそれ ぞれ1例ずつ若干の腫張が認められた。全群ともに, 杯 細胞の増生, ハイェル氏板 2 次濾胞形成が空腸 回腸に
て認められた。胃・盲腸・結腸は, 組織的に著変が認め られなかった。

\section{3. 消化管組㵶形態の SEM による検索}

LM によって組織的に变化の認められた空腸および回 腸の SEM 像を Fig. 3， 4 に示す。DF 無添加群の空腸 は幅が広く, 葉状もしくは舌状の䄉毛像となっていた (Fig. $3 \mathrm{a})$ 。 RBH 添加群は, DF 無添加群之類似した䋐 毛構造であった (Fig. 3 b)。HMP 添加群は, 䄉毛の構 造がやや不規則になり，丸みを帯びた指状の䄉毛像であ った (Fig. 3c)。一方, MCC 添加群の絨毛は, DF 無添 加群の䄉毛之似た構造をしているが, 先端部分が一部開 裂した形態が認められた (Fig. $3 \mathrm{~d}) 。$

回腸になると, 䄉毛構造は, 飼料間の差が他の部位よ りも顕著であった。すなわち, DF 無添加群は, 葉状の 絨毛が幅せまく，規則正しく配列している(Fig. 4 a) の に対し, HMP および MCC 添加群は, 丸みを帯びた指 状の構造が不規則に配列していた(Fig. 4 c, d)。HMP 添 加群は，不規則な䋐毛がかなり広範囲に分布していた。 $\mathrm{RBH}$ 添加群は, HMP 添加群のような顕著な構造が認 められなかった (Fig. 4 b)。 
考察

脂質吸収や代謝実験でよく用いられる条件下で，性質 の異なる $\mathrm{DF}$ 成分をラットに投与した際に起こる消化管 組織の形態变化を，LM ならびに SEM によって検索し た。

DF 無添加， RBH， HMP， MCC 各添加飼料を投与し たラットは，いずれも発育が良好だったことから，2\% 程度の DF の添加量では胃腸管に機能的障害を与えない と考学られる。本研究で用いた $\mathrm{RBH}$ の添加濃度は, 本 物質の実用化を考虑した場合， $0.5 \sim 1 \%$ が適当であり， その数倍量の $\mathrm{RBH}$ による組織形態への影響を検討する ことが合理的であることから，2\%と決定された。ま たこれまでの報告でもへミセルロースの有効濃度は, 0.5 2\% であるとされている6)。

RBH, HMP による消化管の形態は, 空腸〜回腸にか けて一部, 絨毛の腫張が LM によって認められ, 絨毛 構造の形態や間隔・配置が不規則になる傾向があること がSEM によって明らかになった。これらの変化の度合 いは HMP のほうが高く, RBH は，むしろ DF 無添 加群に類似した構造が多かった。この違いは, HMP は 特定の条件下でゲル形成能の強い DF であるのに対し, $\mathrm{RBH}$ は，ホロセルロースの形態から水溶性のへミセル ロース画分を取り出した形態であり ${ }^{17)}$ ，ペクチンのよう な強いゲル形成能がないことに起因していると思われ る。一方, MCC は, 十二指腸〜回晹にかけて, 䋐毛先
端の腫張の頻度が高くなるのが LM によって認められ， 絨毛構造が丸みを帯びた不規則な形態になることが SEM によって明らかになった。LM による所見で認め られた䄉毛の腫張が, SEM では, 絨毛先端部が丸みを 帯びた指状の構造あるいは, 一部開裂した構造として現 れたと考えられる。Gordon ら ${ }^{18)}$ の実験成績によると， セルロース粉末を 0 20\% 飼料に添加してラットに与兄 ると, セルロースレベルを上げるに従い，十二指腸・空 腸でクリプト上皮細胞の有系分裂が活性化するが，この 状態は, 腸全体としては本質的に正常であると述べてい る。また, Jones ら ${ }^{19)}$ は, MCC 10\% 食とペクチン 10 \%食をラットに与えて, 小腸䄉毛パターンを比較してい る。それによると，MCC 食は，DF 無添加食に比べて， 䄉毛パターンはほとんど変化しておらず，ヘクチン食は 䄉毛が隆起し，不規則な形をもったさまざまな形態をと ったと報告している。一方，片山ら 20)は，ラットを用い た実験で，4\%七ルロース食の場合，小腸䋐毛は正常 で，4\%ペクチン食で，小腸䄉毛の配列が不規則にな り，䋐毛先端部の欠損が認められることを報告してい る。本実験で観察された MCC による形態学的変化は, 微結晶形態特有の現象であるのか，これまでの報告が示 すように MCC が䄉毛細胞の更新を促進し, 上皮細胞の 变化を誘発したのかは，さらに実験期間の違い，粒度の 差, 細胞変化の量的な把握などの検討を行らことにより 解明されるであろら。

$\mathrm{RBH}$ に関しては，消化管組織形態に及ぽす影響を検

Fig. 1. LM micrographs of jejunum from rats fed Fiber-free diet (1a), Rice bran hemicellulose diet $(1 \mathrm{~b})$, High-methoxylated pectin diet $(1 \mathrm{c})$, and Microcrystalline cellulose diet $(1 \mathrm{~d})$.

Note the swelling at the villus tips in the HMP and MCC group. Hematoxylin and eosin staining, Magnification $\times 16$.

Fig. 2. LM micrographs of ileum from rats fed Fiber-free diet (2a), Rice bran hemicellulose $\operatorname{diet}(2 \mathrm{~b})$, High-methoxylated pectin $\operatorname{diet}(2 \mathrm{c})$, and Microcrystalline cellulose diet $(2 \mathrm{~d})$.

Note the swelling at the villus tips in the MCC group. Hematoxylin and eosin staining, Magnification $\times 16$.

Fig.3. Villus shapes on the jejunum seen in rats fed Fiber-free diet $(3 \mathrm{a})$, Rice bran hemicellulose diet $(3 \mathrm{~b})$, High-methoxylated pectin diet $(3 \mathrm{c})$, and Microcrystalline cellulose diet $(3 \mathrm{~d})$.

Note the cracks at the villus tips in the MCC group and dull finger-like villi in the HMP group. Magnification $\times 200$.

Fig.4. Villus shapes on the ileum seen in rats fed Fiber-free diet $(4 \mathrm{a})$, Rice bran hemicellulose diet $(4 \mathrm{~b})$, High-methoxylated pectin diet $(4 \mathrm{c})$, and Microcrystalline cellulose diet $(4 \mathrm{~d})$.

Note narrower villus shapes in the ileum of all rats. Finger-like villi are irregular in the HMP and MCC groups, and more prevalent in the former than in the latter. Magnification $\times 200$. 

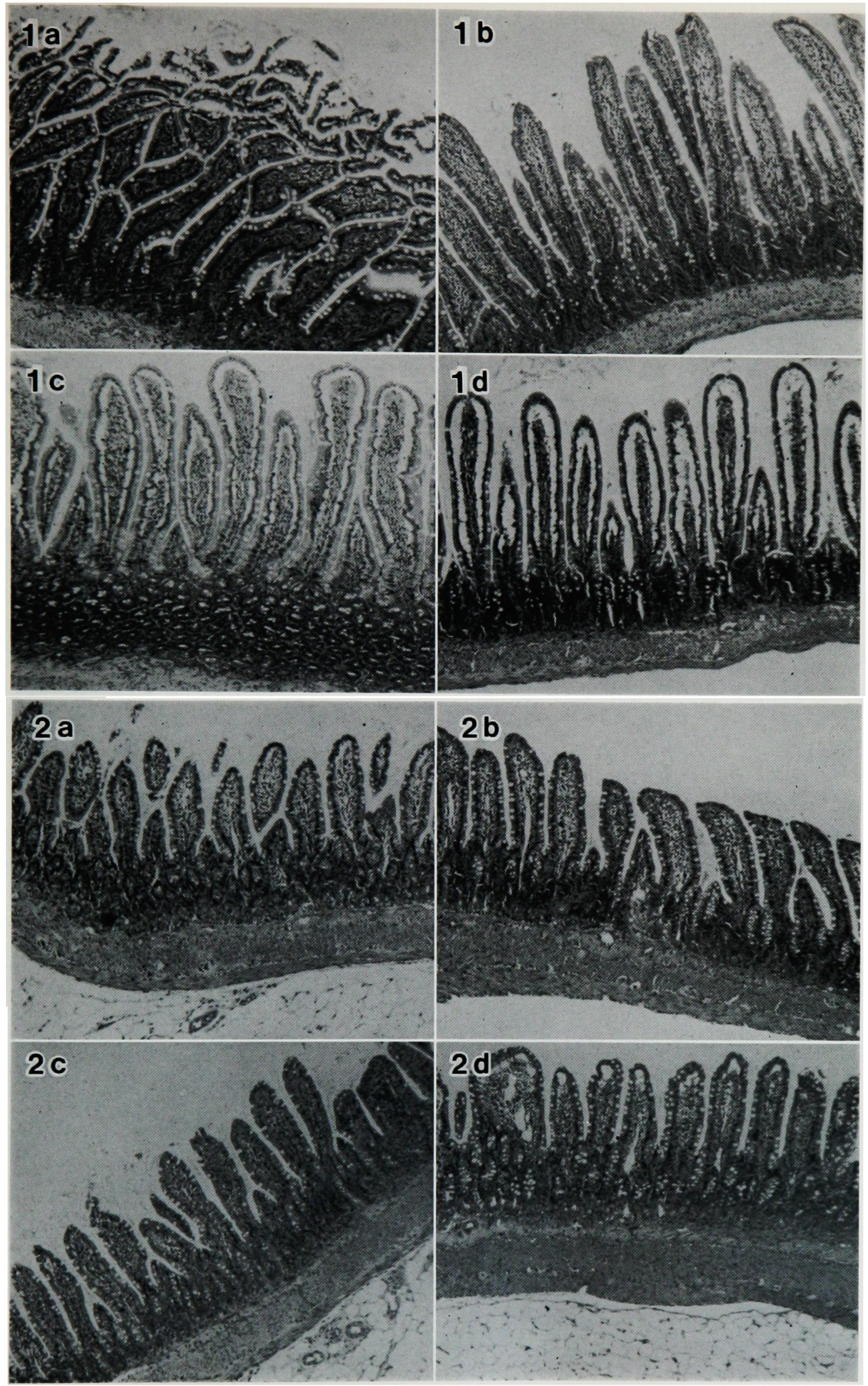


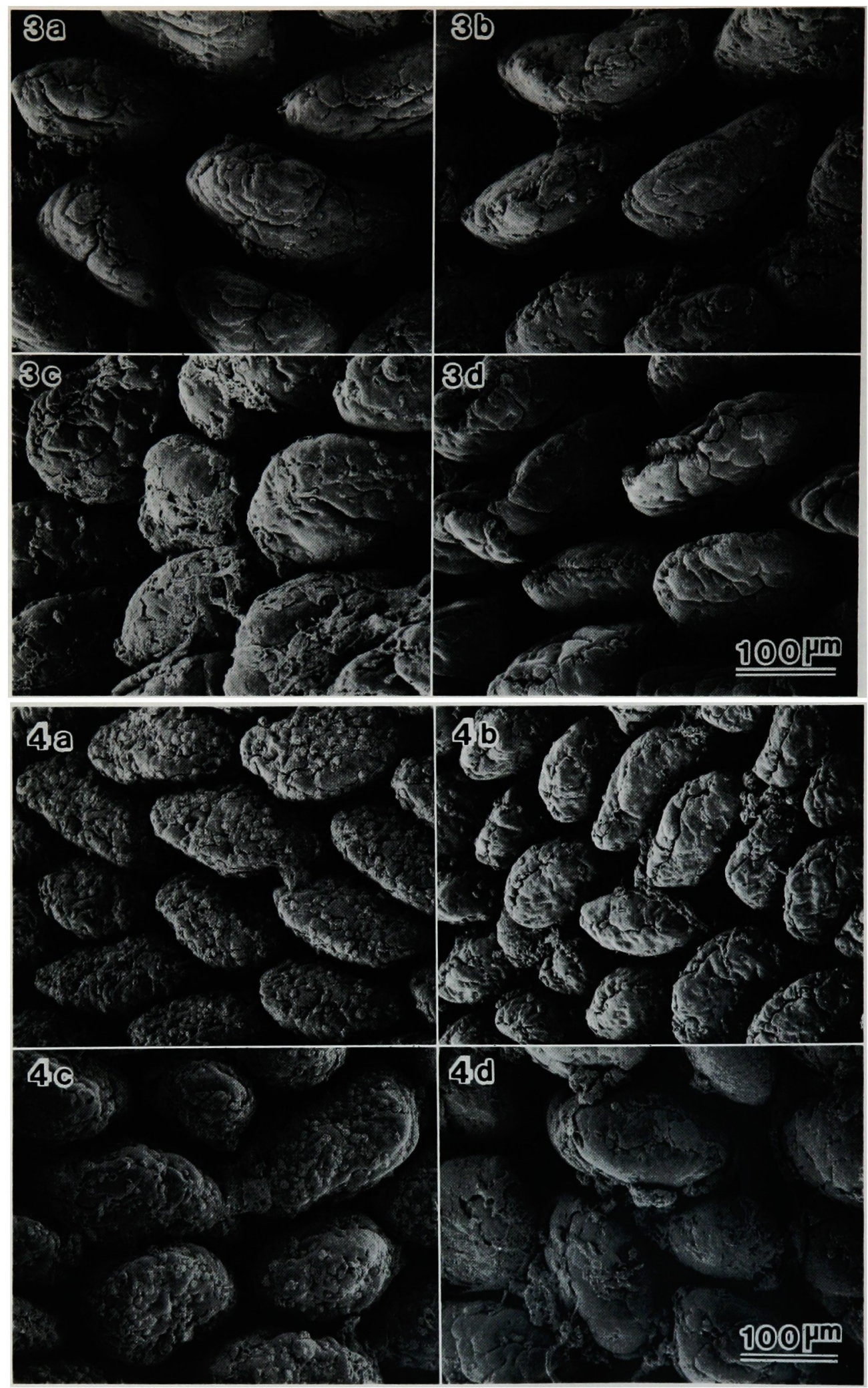


討した報告はないが，HMP や MCC に比べてほとんど 影整ないことが認められた。片山ら201はペクチン $4 \%$ 添加食をラットに与えた場合，小腸形態の变化が現れる のは2 週目以降であると報告している理由から，本実験 の飼育期間を 17 日間とした。しかし， $2 \%$ の RBH の 添加量が長期間投与により消化管の機能に影響を及ぼす かについては,さらに検討する必要があろう。

以上のことより，HMP は，2\%程度の添加量では, 消化管の機能には影響を及ぼさないと考えられる。ま た，MCC は，一部，消化管の器質变化が明らかにされ たか， RBH や HMP と同様に, ラットの発育に影響が みられなかったことから，腸管の機能にまで影響を及ぼ しているとは考えられない。これらの HMP， MCCに 比べて， RBH はほとんど消化吸収に影響はないと考え られる。

\section{要旨}

RBH，HMP，MCC を $2 \%$ 添加した飼料をラットに 17 日間投与し，消化管組織の形態变化について SEM お よび LM による検索を行い，DF 無添加飼料を投与し たラットと比較した。

1）水溶性 DF である $\mathrm{RBH}$ および HMP を投与し たラットの空腸の絨毛に, 若干の腫張が起こることが LM 検索により認められ, 空腸〜回腸の䋐毛の間隔・配 置が不規則になる傾向があることが SEM により明らか にされた。変化の度合いは，HMP 投与ラットのほうが 高かった。しかし，ラットの発育が DF 無添加群よりも 良好であったことから，これら変化が消化管の機能にま で影響を及ぼしているとは考えられない。

2）不溶性 DF である MCCを投与したラットの十二 指腸〜回腸の䄉毛先端に, 腫張が起こることが LM 検索 により認められた。䄉毛形態そのものは，水溶性 DF ほ その変化か：SEM により認められなかった。MCCによ るこの消化管の器質変化も水溶性 DF と同様に, 腸管の 機能にまで影響を及ぼしているとは考えられない。

本研究を実施するにあたり, 走査型電子顕微鏡検索に おい, 雪印乳業(株)技術研究所 相良康重氏心, 組織標
本検索におい、ては，雪印乳業(株)生物科学研究所 侍園 貞雄氏の協力に感謝します。また，本論文を作成するに あたってご指導をいただきました理研 水谷武夫博士に 深謝いたします。

\section{文献}

1) Kay, R.M. and Strasberg, S.M. : Clin. Invest. Med., 1, 9 (1978)

2) Krichevsky, D. : Am. J. Pathol., 84,615 (1976)

3) Cassidy, M.M., Lightfoot, F.G., Gram, L.E., Story, J.A., Krichevsky, D. and Vahouny, G.V. : Am. J. Clin. Nutr., 34, 218 (1981)

4) Jacobs, J.R. and Schneeman, B.O. : J.Nutr., 111, 798 (1981)

5) Paulini, I., Mehta, T. and Hargis, A. : $J$. Nutr., 117, 253 (1987)

6) 綾野雄幸, 太田富貴雄, 渡辺幸雄, 三田浩三, 中 村 強: 食物瀻維 (印南 敏, 井上五郎 他編), 201 (1983), 篠原出版 (東京)

7) 青江誠一郎, 太田富貴雄, 綾野雄幸: 栄食誌, 41, 203 (1988)

8) Keys, A., Grande, F. and Anderson, J.T.: Proc. Soc. Exp. Biol. Med., 106, 555 (1961)

9) Palmer, G.H. and Dixon, D.G. : Am. J. Clin. Nutr., 18, 437 (1966)

10) Kay, R.M. and Truswell, A.S. : Am. J. Clin. Nutr., 30, 171 (1977)

11）石井静江, 長谷川忠雄, 鈴木隆雄 : 栄養之食糧, 33, 297 (1980)

12) Southgate, D.A.T.: The analysis of Dietary Fiber in Food (James, W.P.T. and Theander, O., eds), 1 (1981) Marcel Dekker, Inc. (New York)

13）上野民夫：化学と生物，8，114（1970）

14) Bitter, T. and Muir, H. : Anal. Biochem., 4, 330 (1962)

15）日本病理学会 (編): 病理組織標本作製技術（上, 下) (1981), 医歯薬出版 (東京)

16）日本電子顕微鏡学会関東支部(編)：電子顕微鏡生 物試料作製法 (1975), 丸善 (東京)

17）綾野雄幸：食物緎維（印南 敏, 桐山修八 編) (1982) 第一出版 (東京)

18) Gordon, D.T., Williford, C.B. and Ellersieck, M.R. : J. Nutr., 113, 2545 (1983)

19) Jones, C.T., Owen, R.L. and Jones, A.L. : Dig. Dis. Sci., 27, 6 (1982)

20）片山（須川）洋子, 菊崎泰枝, 泉田明子: 栄食誌, 40, 64 (1987)

(1988 年 8 月 19 日受理) 